Instytut Historii i Stosunków Międzynarodowych

Uniwersytet Szczeciński

MARIAN RĘBKOWSKI

\title{
Od grodu książęcego do rezydencji prepozyta kapituły. Lubin w XI-XVI wieku
}

\section{From ducal stronghold to chapter provost's residence. Lubin in the $11^{\text {th }}-16^{\text {th }}$ centuries}

\begin{abstract}
Zarys treści. Wyniki badań wykopaliskowych przeprowadzonych w Lubinie w latach 2008-2011 oraz źródła pisane dały podstawę do rekonstrukcji osadniczej przeszłości wzgórza grodowego w średniowieczu i wczesnej nowożytności, zmieniających się w tym czasie jego funkcji oraz uwarunkowań tych przekształceń. Najstarsze ślady średniowiecznego osadnictwa należy datować na koniec IX wieku lub 1. połowę następnego stulecia. Sam gród został jednak wedle wszelkiego prawdopodobieństwa wzniesiony dopiero w 2. połowie XI wieku. W 1124 roku biskup Otton z Bambergu zbudował w nim jedną z najstarszych świątyń chrześcijańskich Pomorza. Kres znaczenia grodu nastąpił po jego zdobyciu i zniszczeniu w 8. dekadzie XII wieku przez Duńczyków. W 1186 lub 1187 roku został on przekazany kapitule kamieńskiej. W XIII wieku w miejscu dawnej osady obronnej dalej funkcjonował kościół, pełniący funkcje parafii oraz cmentarz. W następnym stuleciu doszło do całkowitej zmiany w zagospodarowaniu przestrzennym wzniesienia: kościół przeniesiono na sąsiednie wzgórze, dawne umocnienia zniwelowano, a wkrótce potem zbudowano wieżę mieszkalną, która stała się siedzibą prepozyta kapituły katedralnej z Kamienia. Obiekt został rozebrany dopiero w końcu XVI wieku, po powrocie dóbr lubińskich w ręce książąt szczecińskich.
\end{abstract}

Słowa kluczowe: średniowiecze, archeologia, wyspa Wolin.

Jedną z najstarszych nazw miejscowych Pomorza Zachodniego, jakie zostały zapisane w średniowiecznych źródłach, jest Lubin. Pojawia się ona w powstałych w połowie XII wieku żywotach biskupa bamberskiego Ottona, przy okazji opisów jego pierwszej pomorskiej podróży misyjnej z lat 1124-1125 (por. niżej). Nazwa ta, 
pochodząca najprawdopodobniej od nazwy osobowej o formie Luba bądź też Łuba (Rzetelska-Feleszko, Duma 1991, s. 78-79), łączona jest przez całą historiografię z miejscowością Lubin (obecnie gmina Międzyzdroje), położoną na południowo-zachodnim skraju wyspy Wolin, tuż nad Zalewem Szczecińskim i ujściem Starej Świny do Bałtyku. Na jednym ze znajdujących się tam morenowych wzniesień, dominujących nad Zalewem, co najmniej od XIX wieku identyfikowano pozostałości grodu wzmiankowanego w XII-wiecznych przekazach pisanych. Informacja o grodzisku pojawiała się w większości katalogów wczesnośredniowiecznych obiektów obronnych Pomorza (np. Behla 1888, s. 144: 4; Łęga 1930, s. 517; Kunkel 1937, s. 4; por. też Eggers 1960, s. 41; 1978, s. 230; Filipowiak 1962, s. 139-141). Wyniki przeprowadzonych na nim w latach 2008-2011 badań wykopaliskowych ${ }^{1}$, wraz ze starszymi odkryciami i całkiem pokaźnym zestawem źródeł pisanych, pozwalają prześledzić zmieniający się w ciągu średniowiecza i czasów nowożytnych charakter osadnictwa i funkcje lokalizowanych na wzniesieniu obiektów.

Zacząć wypada od zwrócenia uwagi na specyfikę położenia geograficznego miejscowości, usytuowanej na wzniesieniach moren czołowych przylegających do Zalewu Szczecińskiego. Szczególnego podkreślenia wymaga lokalizacja niemal na granicy dwóch mezoregionów: wału morenowego zakończonego od strony wody wysoką falezą, nazywanego Pagórkami Lubińsko-Wapnickimi oraz tzw. Bramy Świny, czyli nisko położonego obszaru przybrzeżnej akumulacji morskiej i eolicznej (Kondracki 1998, s. 48). Oznacza to, że osadnictwo od początku rozwijało się tutaj na wysokiej platformie przewyższającej o kilkadziesiąt metrów powierzchnię wody przylegającego do niej Zalewu Szczecińskiego. Swoje maksimum wysokości bezwzględne osiągają na wzgórzu grodowym, mającym obecnie kształt zbliżony do rombu o powierzchni około 1,5 ha, bardzo wyraźnie rysującego się w otaczającej przestrzeni. Jego plateau, nachylone lekko ku wschodowi, osiąga wysokość w granicach od blisko $44 \mathrm{~m}$ n.p.m. do ponad $52 \mathrm{~m}$ n.p.m. Lokalizacja taka może wskazywać na strategiczne znaczenie Lubina w przeszłości; jego położenie dawało możliwość kontroli nad jedną z trzech, obok Piany i Dziwny, cieśnin łączących Zalew Szczeciński z Zatoką Pomorską (Kiersnowski 1951, s. 210-211; Kowalenko 1954, s. 17-18, 58-60; Gaziński 2006, s. 140-142).

W świetle dotychczasowego rozpoznania terenowego w Lubinie i jego najbliższej okolicy zlokalizowano siedem stanowisk archeologicznych, datowanych na młodsze fazy wczesnego średniowiecza, wśród których oprócz wzmiankowanego powyżej grodziska (stanowisko 1) znajduje się cmentarzysko (stanowisko 6) i pięć osad (Archiwum Muzeum Narodowego w Szczecinie, teczka 1775; Filipowiak

${ }^{1}$ Badania przeprowadzone były przez Ośrodek Archeologii Średniowiecza Krajów Nadbałtyckich w Szczecinie Instytutu Archeologii i Etnologii PAN we współpracy z Katedrą Archeologii Instytutu Historii i Stosunków Międzynarodowych Uniwersytetu Szczecińskiego. Prace terenowe sfinansowane zostały przez Gminę Międzyzdroje. Monografia stanowiska jest przygotowywana w ramach projektu 0212/NPRH2/H11/81/2013, pt. „Ujście Odry we wczesnym średniowieczu. Wolin i Lubin - edycja źródeł archeologicznych". 


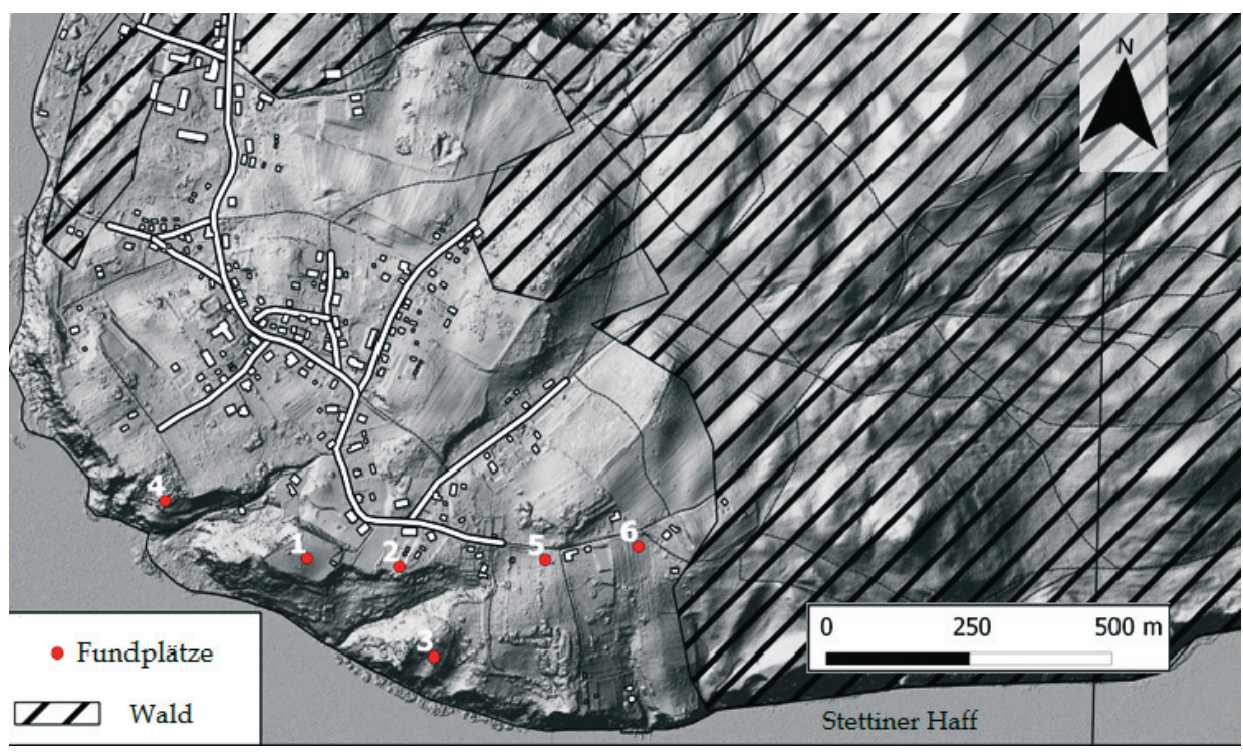

Ryc. 1. Lubin, wyspa Wolin. Rozmieszczenie stanowisk archeologicznych datowanych na wczesne średniowiecze: 1 - grodzisko, 2-5 - osady, 6-cmentarzysko (oprac. G. Kiarszys)

Fig. 1. Lubin, Wolin island. Distribution of archaeological sites dated to the early Middle Ages: 1 - stronghold, 2-5 - settlements, 6- cemetery (prepared by G. Kiarszys)

1962, s. 139-144). Trzy z tych stanowisk poddawane były dotychczas badaniom wykopaliskowym o różnym charakterze. W 1937 roku, kilkaset metrów na północny wschód od grodziska, przy drodze prowadzącej do Dargobądza, odkryto przypadkowo przy kopaniu fundamentów pod dom trzy groby szkieletowe. Znalezione w jednym z nich całkowicie obtaczane naczynie pozwoliło datować pochówki na młodsze fazy wczesnego średniowiecza. Niewykluczone, że z tym właśnie cmentarzyskiem związany był jeszcze jeden grób, odkryty przypadkowo w 1934 roku, o którym nie zachowały się jakiekolwiek bliższe informacje (AMN, teczka 1775; Filipowiak 1959, s. 319-320; 1962, s. 143-144).

W 1954 roku przeprowadzono ratownicze badania archeologiczne o niewielkim zakresie w obrębie osady zlokalizowanej na wschód od grodziska, na skraju wysoczyzny morenowej stromo opadającej w kierunku Zalewu Szczecińskiego i oznaczonej jako stanowisko 3. Na podstawie pozyskanego materiału ceramicznego autor badań datował funkcjonowanie osady na okres od IX po XII stulecie (Filipowiak 1959, s. 311-317; 1962, s. 142).

Samo grodzisko było przedmiotem zainteresowań naukowych od dawna, co najmniej od 1. połowy XIX wieku. Działo się tak ze względu na łączenie obiektu z przebiegiem misji biskupa Ottona, a tym samym z powodu jego znaczenia dla początków chrześcijaństwa na Pomorzu, jak też w związku z przypadkowym 


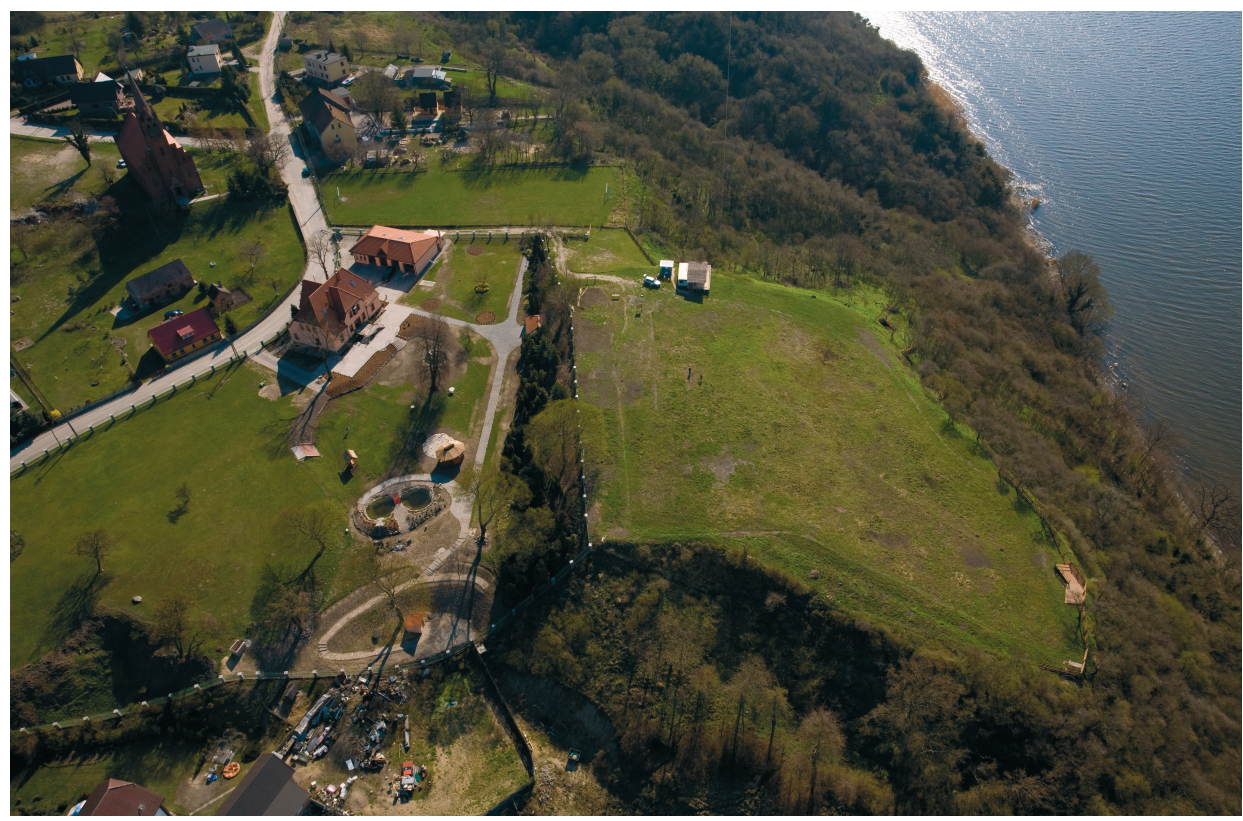

Ryc. 2. Lubin, wyspa Wolin. Grodzisko z lotu ptaka - widok od północnego zachodu (fot. M. Bogacki)

Fig. 2. Lubin, Wolin island. Aerial view of the stronghold - view from the north-west (photo M. Bogacki)

odkryciem skarbu monet arabskich, jakiego dokonano tam jeszcze w końcu XVIII wieku. Analiza pewnej jego części - dzisiaj, niestety, także zaginionej - pozwoliła na stwierdzenie, że skarb został ukryty wkrótce po połowie X wieku (Zöllner 1797, s. 88-90; Kiersnowscy 1959, s. 61; Eggers 1978, s. 19). W latach 1831 i 1840 rozkopywano obiekt szukając pozostałości kościoła założonego przez biskupa Ottona w 1124 roku. O charakterze i zasięgu tej działalności niewiele jednak wiadomo (Archiwum Muzeum Narodowego w Szczecinie, teczka 1775; Berghaus 1865, s. 642). Prospekcji terenowych, w trakcie których rejestrowano zabytki ruchome, dokonywano kilkakrotnie w 2. połowie XIX wieku, a także w poprzednim stuleciu (Virchow 1872, s. 61; Küster 1891, s. 6-8; Stubenrauch 1898, s. 83). Przeprowadzone w latach 2008-2011 badania wykopaliskowe objęły swym zasięgiem nieco ponad $350 \mathrm{~m}^{2}$ powierzchni obiektu, głównie w zachodniej części wzgórza grodowego. Mimo stwierdzenia dużego stopnia zniszczeń nawarstwień kulturowych i wielokrotnych niwelacji, jakie miały miejsce na plateau wzniesienia, badania doprowadziły między innymi do odkrycia reliktów kościoła pod wezwaniem św. Mikołaja i towarzyszącego im cmentarzyska, pozostałości dwóch faz wału, reliktów murowanej zabudowy późnośredniowiecznej i wczesnonowożytnej oraz do rozpoznania sekwencji chronologicznej nawarstwień kulturowych, zwłaszcza w północno-zachodniej części obiektu. 
Przeprowadzone przed laty studia osadnicze Władysława Łosińskiego dowiodły, że rozwój wczesnośredniowiecznego osadnictwa w południowo-zachodniej części wyspy Wolin, zwłaszcza na szczególnie interesującym nas tutaj obszarze, należy datować dopiero na X stulecie (Losiński 1982, s. 45-48, 149, ryc. 8, 9). Z tą oceną dobrze korespondują wyniki ostatnich badań wykopaliskowych przeprowadzonych w Lubinie. Na ich podstawie najstarsze ślady zasiedlenia we wczesnym średniowieczu wzgórza dominującego nad Zalewem Szczecińskim i nasadą ujścia Świny, można datować na koniec IX lub na 1. połowę X stulecia. Być może z tego okresu pochodzą słabo zachowane warstwy kulturowe zarejestrowane w północno-zachodniej części obiektu, zawierające zespół fragmentów naczyń częściowo obtaczanych na kole. Nie mamy jednak pewności, czy nie znalazły się tam one na wtórnym złożu, jak to bez wątpienia miało miejsce w przypadku fragmentów takich naczyń odkrywanych w innych kontekstach stratyfikacyjnych (Dworaczyk, Durdyń w druku). Trudno tym samym rozstrzygnąć, jaki był charakter tej domniemanej najstarszej osady i czy już wówczas mogła być otoczona wałem obronnym. Prawdopodobnie kres tej fazy zasiedlenia wzgórza wyznacza moment zdeponowania skarbu dirhemów w pierwszych latach po połowie X stulecia. Najprawdopodobniej mniej więcej w tym samym czasie osadnictwo pojawiło się na sąsiednim wzniesieniu (stanowisko 3). W trakcie badań ratowniczych przeprowadzonych tam w 1954 roku stwierdzono, że najstarszy poziom osadniczy wyznacza jama zawierająca wyłącznie ułamki naczyń częściowo obtaczanych (Filipowiak 1959, s. 316).

Bez względu na charakter najstarszego osadnictwa, przełomowym momentem w dziejach zasiedlenia wzgórza było usypanie wałów grodu w następnym wieku. Wedle wszelkiego prawdopodobieństwa nastąpiło to po trwającym około stulecia hiatusie osadniczym. Pozostałości wału z tego okresu przetrwały w postaci nasypów gliniasto-piaszczystych, wzmocnionych swego rodzaju kamienną stopą o szerokości przekraczającej $1 \mathrm{~m}$, biegnącą wzdłuż wału. Umocowano na nich konstrukcje drewniane (palisada?), po których zachowały się jedynie negatywy słupów, a całość obłożona została glinianym płaszczem. Na podstawie oceny struktur zbiorów ceramicznych pozyskanych z nasypu wału oraz najstarszych nawarstwień odkrytych wewnątrz grodu, jego budowę należy sytuować w 2. połowie XI wieku lub gdzieś na przełomie XI i XII stulecia (Dworaczyk, Durdyń w druku).

Przebieg wału, układającego się w północnej części wzniesienia w kierunku mniej więcej północny zachód-południowy wschód wskazuje, że gród raczej nie obejmował swym zasięgiem całego plateau. Nie mamy też pewności, czy obiekt miał kształt pierścieniowaty, czy też wał jedynie odcinał półkoliście dostęp do osady od strony lądu. Z pewnością w jego wnętrzu znajdowała się zachodnia, wyższa część wzniesienia. Budowa wału jeszcze bardziej uwydatniała i tak z natury obronne położenie wzgórza, od północnego zachodu i od południowego wschodu odciętego przez głębokie parowy wrzynające się od strony Zalewu Szczecińskiego w wysoczyznę morenową. Dostęp do grodu był możliwy jedynie od strony północno-wschodniej pasem o szerokości kilkudziesięciu metrów. Zalety 




Ryc. 3. Lubin, wyspa Wolin. Mapa warstwicowa wzgórza grodowego z zaznaczonymi wykopami archeologicznymi z lat 2008-2011 (oprac. A. Janowski)

Fig. 3. Lubin, Wolin island. Contour map of the stronghold hill with marked archaeological trenches from 2008-2011 (prepared by A. Janowski)

obronne takiej lokalizacji w połączeniu z usytuowaniem wysoko ponad Zalewem, nadawały grodowi walor strategiczny, pozwalający na kontrolę Świny, a więc jednej z trzech, obok Piany i Dziwny, cieśnin łączących Zalew z Zatoką Pomorską i otwartym morzem.

Z tym okresem funkcjonowania obiektu obronnego, a więc z końcem XI wieku i pierwszym ćwierćwieczem następnego stulecia trzeba wedle wszelkiego prawdopodobieństwa łączyć użytkowanie cmentarza, położonego w odległości kilkuset metrów na północny wschód od grodu. Cmentarzysko należy zaliczyć do grupy najstarszych na Pomorzu nekropoli szkieletowych, datowanych od końca X do 1. ćwierci XII wieku, koncentrujących się wzdłuż dolnej Odry. Oprócz lokalizacji w pobliżu ważnych grodów, charakteryzuje je między innymi nieregularna orientacja zmarłych (Rębkowski 2007, s. 117 i nn., 151-152). Zaprzestanie jego użytkowania musiało być konsekwencją zbudowania na terenie grodu w 1124 roku kościoła, przy którym wkrótce potem powstał nowy cmentarz.

Właśnie w związku z tymi wydarzeniami po raz pierwszy w źródłach pisanych pojawiła się informacja o Lubinie. Jak podają dwaj z trzech autorów żywotów biskupa Ottona z Bambergu, Herbord (Herbord, II, 37) i Mnich z Preflingen (VP, II, 14), 


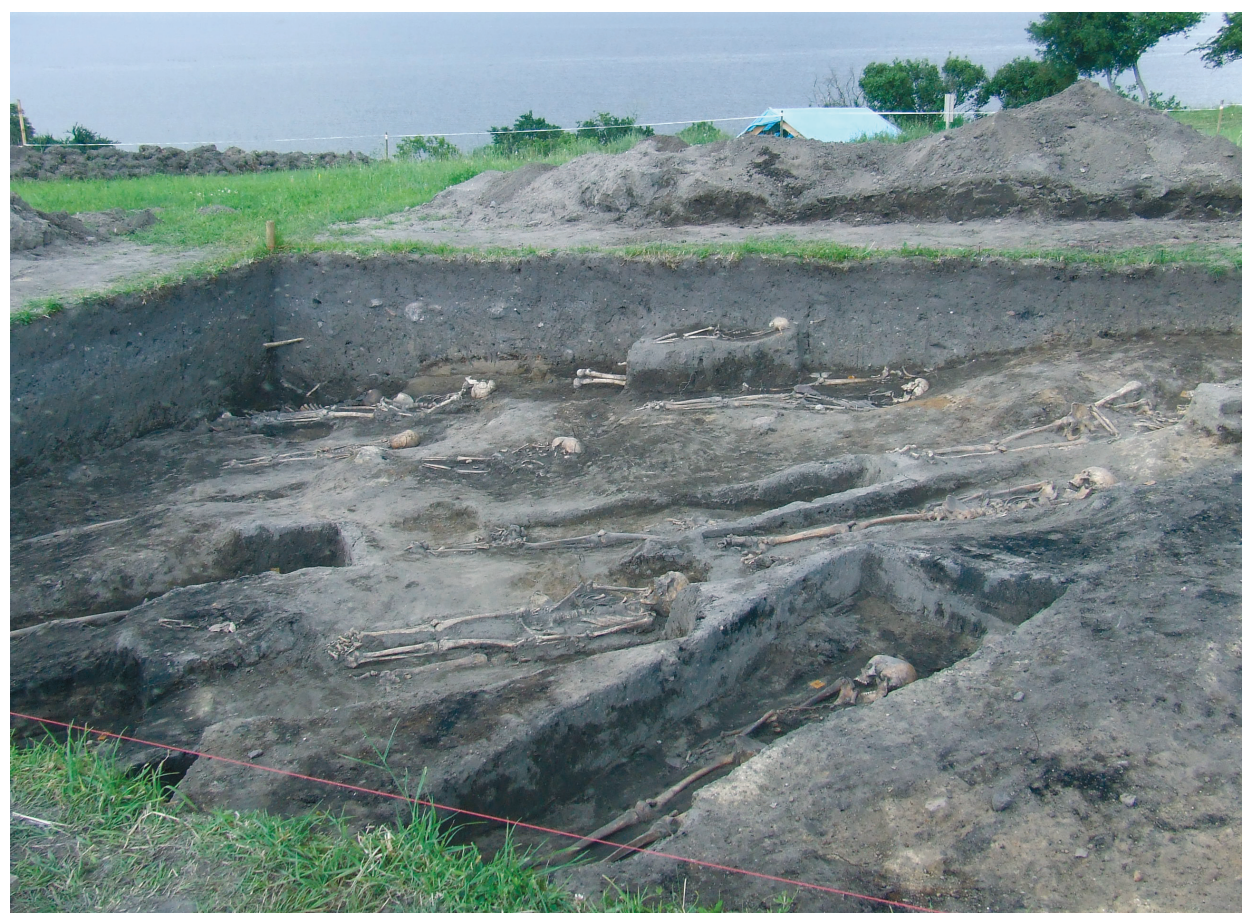

Ryc. 4. Lubin, wyspa Wolin. Fragment cmentarzyska odkrytego na grodzisku - widok od północy (fot. M. Rębkowski)

Fig. 4. Lubin, Wolin island. Part of the cemetery discovered on the stronghold - view from the north (photo M. Rębkowski)

misjonarz nie tylko odwiedził miejscowość, ale także wzniósł tam kościół (por. np. Hofmeister 1924, s. 16; Rębkowski 2007, s. 32; Rosik 2010, s. 302). Sam Lubin określany był przy okazji jako gród (castellum) bądź miasteczko (civitatula). Późniejszy o kilkadziesiąt lat dokument księcia Bogusława I potwierdza istnienie w grodzie kościoła, który miał nosić wezwanie św. Mikołaja (PUB I, nr 102). Jego relikty zostały częściowo odsłonięte w 2009 roku (Rębkowski 2016). Teren pod budowę świątyni wybrano w północno-zachodniej części grodu, niemal dokładnie w miejscu kulminacji wyniesienia. Niewielki, jednonawowy kościół wzniesiony został na kamienno-glinianej ławie, na której osadzono drewniane słupy, a powierzchnię ścian wypełniono plecionką i gliną. Inwestycja oznaczała również przynajmniej częściową reorganizację przestrzeni wewnątrz obwałowań, tym bardziej, że wkrótce na południe od kościoła, w miejscu wcześniejszej zabudowy, wyznaczono przestrzeń grzebalną. Tym razem, w przeciwieństwie do starszego, podgrodowego cmentarza, była to jednak nekropola, na której zmarli orientowani byli regularnie, zgodnie z orientacją świątyni, a po pewnym czasie nabrała cech cmentarza wielowarstwowego. 
Wybór Lubina na miejsce, gdzie wzniesiono jeden z pierwszych pomorskich kościołów, wskazuje nie tylko na jego istotne znaczenie polityczne, ale też pozwala na domysły, że znajdowało się tam znaczące skupisko ludności. Pośrednio potwierdza to w swym przekazie wspomniany wyżej autor jednego z żywotów biskupa Ottona, nazywający Lubin miasteczkiem, a w jakiejś mierze dowodzi także rozpoznanie archeologiczne okolicy. Na podstawie materiałów, znanych co prawda jedynie z badań powierzchniowych, oprócz grodu mogło wówczas istnieć wokół niego kilka osad otwartych. Jedna z nich kilkadziesiąt lat później, w przywoływanym już wyżej dokumencie księcia Bogusława I określona została jako „wik”, co może wskazywać na jej gospodarcze znaczenie (PUB I, nr 102 - vicus ante ipse castrum; por. też Leciejewicz 1983, s. 127-128).

Powyższe dane dowodzą, że już w 3. dekadzie XII wieku Lubin kreowany był na ważny punkt w krystalizującej się wówczas strukturze organizacji terytorialnej księstwa zachodniopomorskiego. Przypomnijmy, że zarząd tery torialny księstwa został oparty na dwustopniowym systemie grodowo-kasztelańskim, w którym grodom kasztelańskim podlegały jednostki określane w źródłach dyplomatycznych mianem provincia lub terra. To właśnie one stanowiły podstawową jednostkę podziału terytorialnego księstwa (Ślaski 1960; Spors 1991; Leciejewicz 1993, s. 68-70). Centrami prowincji, analogicznie jak w przypadku kasztelanii, były zazwyczaj - z nielicznymi wyjątkami - grody. Funkcję głównego ośrodka prowincji spełniał również Lubin, czego dowodzi chociażby wzmiankowany dokument z 1186 lub 1187 roku, w którym miejscowość opisana została jako ośrodek okręgu grodowego. W historiografii istnieje jednak rozbieżność ocen co do tego, w skład której kasztelanii miałaby wchodzić prowincja lubińska. Zdawać by się mogło, że położenie na wyspie winno niemal jednoznacznie wskazywać na przynależność do kasztelanii wolińskiej. Jednak informacja zapisana przez Herborda (Herbord, II, 37) wskazuje, że wraz z innym grodem Lubin miał być położony na krańcu okręgu szczecińskiego: in confinio posita ad pagum pertinebant Stetinensem. Oznaczałoby to, że kasztelania szczecińska obejmowała na północy także zachodnią część wyspy Wolin (Ślaski 1960, s. 85-87). Nie brak było jednak opinii całkowicie podważających przekaz Herborda albo też sugerujących, że opisana tam przynależność okręgu lubińskiego do kasztelanii szczecińskiej była czasowa i krótkotrwała, podczas gdy normalnie wchodził on w skład kasztelanii wolińskiej (Spors 1988, s. 97-98; 1991, s. 60-61).

W 2. połowie XII wieku wał grodu został spalony, a następnie odbudowany. Przynajmniej w północnej części jego przebieg lekko odbiegał od poprzedniego; przy budowie, po częściowych niwelacjach starszego obiektu, doszło do przesunięcia przebiegu wewnętrznego skraju wału na południe, w kierunku wnętrza grodu. Nasyp, tym razem o zachowanej miąższości dochodzącej do $1,5 \mathrm{~m}$, składał się z szeregu piaszczystych i gliniastych warstw, zawierających średniej i drobnej wielkości kamienie polne. Odkryto w nim także ślady sprasowanych i doszczętnie spalonych konstrukcji drewnianych (najprawdopodobniej skrzynie, 
niewykluczona przekładka). Źródła archeologiczne w połączeniu z serią datowań radiowęglowych wskazują, że przebudowę umocnień należałoby datować na 7. lub 8. dekadę XII stulecia (Dworaczyk, Durdyń w druku). Trudno zatem nie łączyć tych wydarzeń z najazdem, w trakcie którego Lubin został zdobyty przez wojska duńskiego króla Waldemara I, wracającego do swojego kraju po oblężeniu Szczecina (Saxo Grammaticus XIV, 43, 5). Wydarzenie datowane jest powszechnie na 1173 rok (Eggert 1927, s. 58-59, 95, 145; 1928, s. 56), chociaż istniejąc przesłanki wskazujące, że mogło się to stać trzy lata później (por. ostatnio Guzikowski 2016, s. 96-97).

W literaturze przedmiotu dość zgodnie przyjmuje się, że zdobycie grodu lubińskiego równoważne było z jego zniszczeniem. Zgadzając się z tym przekonaniem nie jesteśmy jednak w stanie wykazać, czy budowa nowych umocnień była tych zniszczeń skutkiem, czy też podjęto ją jeszcze przed najazdem duńskim, celem podniesienia jego walorów obronnych. Następstwa zdobycia i zniszczenia grodu miały jednak - jak się okazało - decydujące znaczenie dla dalszych jego losów. Na taką ocenę pozwala późniejsza o ledwie kilkanaście lat informacja o przekazaniu przez Bogusława I Lubina wraz z kościołem pod wezwaniem św. Mikołaja i całym okręgiem grodowym kapitule kościoła katedralnego w Kamieniu (PUB I, nr 102). Oznaczało to kres istnienia grodu i spełnianych przezeń funkcji administracyjnych. Od tego momentu nigdy więcej informacja o nim nie pojawiła się w źródłach pisanych. W następnym stuleciu, w 1242 roku, jeden z pomorskich książąt wystawi dokument po prostu in Liubin (CDP, nr 306), a kilkanaście lat później, w 1256 roku, miejscowość opisana zostanie już jako wieś (PUB II, nr 621 - villa Lubin).

Pomimo upadku grodu, w XIII wieku w dalszym ciągu funkcjonował jednak dawny grodowy kościół. Użytkowany był również przylegający doń cmentarz, czego dowodzą zarówno odkryte w grobach przedmioty, w tym monety, z których najmłodsze wybite zostały w tym stuleciu, jak i rozbudowanie kościoła o kamienną wieżę (Rębkowski 2016). Budynek musiał wówczas spełniać rolę świątyni parafialnej dla wsi, która - jak się domyślamy - rozwinęła się w dobie kolonizacji. Na wyspie Wolin związane z nią zmiany przestrzenne i prawne dotarły dopiero w ostatnim ćwierćwieczu XIII stulecia (Piskorski 1990, s. 153). Nie jest zapewne dziełem przypadku, że na ten właśnie czas przypada zaprzestanie użytkowania kościoła i cmentarza w miejscu dawnego grodu. Wzmianki źródłowe z lat 1321-1322 (PUB VI, nr 3515, 3639), w których wymieniana jest nie tylko świątynia w Lubinie, ale też jej pleban Maurycy, wedle wszelkiego prawdopodobieństwa musiały dotyczyć już tego nowego obiektu, wzniesionego najpewniej w miejscu, gdzie znajduje się dzisiaj kościół².

Jak można przypuszczać, jedną z przyczyn zmiany lokalizacji kościoła parafialnego był zamiar nowego zagospodarowania wzgórza grodowego przez kapitułę

${ }^{2}$ Zachowany do dzisiaj budynek kościoła w Lubinie powstał dopiero w połowie XIX wieku (Lemcke 1900, s. 366). 


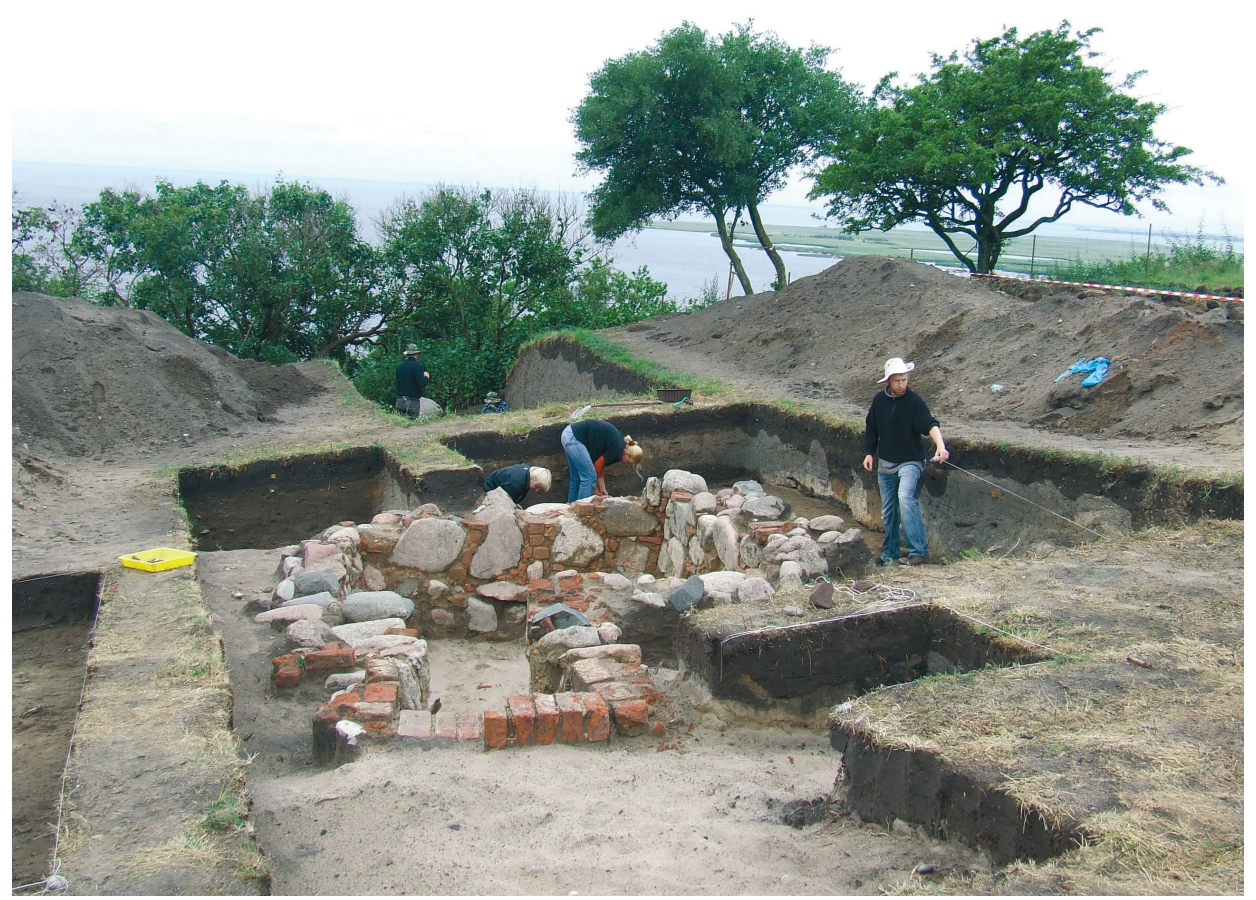

Ryc. 5. Lubin, wyspa Wolin. Fundamenty wieży mieszkalnej w trakcie badań (fot. M. Rębkowski)

Fig. 5. Lubin, Wolin island. Foundations of the tower house during the excavations (photo M. Rębkowski)

kamieńską. Najprawdopodobniej jeszcze w XIV wieku zniwelowano, przynajmniej częściowo, pozostałości dawnych obwałowań i wyrównano teren w okolicach południowej części zbocza. W końcu tego stulecia lub w następnym wieku na zewnętrznym skłonie zniwelowanej północnej części wału wzniesiono murowany budynek, którego pozostałości - po jeszcze późniejszych niwelacjach - zachowały się tylko szczątkowo. W znacznie lepszym stanie przetrwały natomiast relikty budynku wieżowego, zagłębionego w ziemi na około 1,5 m, odkryte w południowej części wzgórza. Na kamiennym fundamencie, który w rzucie miał wymiary około 4,0×3,8 m, wzniesiono dwie kondygnacje, $\mathrm{z}$ których pierwsza była ceglana, druga zaś szachulcowa. Wejście do piwnicy z zewnątrz, z poziomu powierzchni ziemi, a także inne elementy wskazują, że nie miał on charakteru obronnego, a pełnił wyłącznie funkcje mieszkalne. Rezydencjonalny charakter wieży potwierdzają znaleziska pochodzące z zasypiska obiektu, wskazujące na dbałość o komfort jego mieszkańców. Wyrazem tego było ogrzewanie piecowe budynku, malowanie ścian jego wnętrza, czy szklenie okien (Rębkowski, Romanowicz 2015).

Konfrontacja powyższych odkryć ze źródłami pisanymi pozwala stwierdzić, że wieża, której relikty odkryto w 2010 roku była wykorzystywana jako rezydencja 
prepozyta kapituły kamieńskiej w czasie jego pobytów w Lubinie. W opisie lubińskich dóbr, wykonanym w 1578 roku, znajduje się informacja o istnieniu budynku murowanego określanego mianem Bergfried, spełniającego takie właśnie funkcje (Raumer von 1851, s. 102). Zawarto tam, niejako przy okazji, spostrzeżenie mówiące o pięknie widoku rozciągającego się ze wniesienia na Zalew Szczeciński. Traktować je można jako nowy, typowy już dla elit renesansowych czynnik warunkujący wybór miejsca pod budowę rezydencji.

Okres przynależności Lubina do kapituły, rozpoczęty w końcu XII wieku, dobiegł końca w 2. połowie XVI wieku. Po długoletnim sporze posiadłości lubińskie wróciły w posiadanie książęce na mocy umowy podpisanej w 1569 roku, między prepozytem kapituły kamieńskiej Ludwikiem von Ebersteinem a księciem szczecińskim Janem Fryderykiem (Raumer von 1851, s. 94-101; Berghaus 1865 , s. 644-645). Wkrótce, jeszcze w XVI wieku, wieża mieszkalna została rozebrana, a teren dawnego grodziska poddany kolejnym niwelacjom. Wyniki dotychczasowych badań archeologicznych nie dostarczyły danych wskazujących na jakiekolwiek inwestycje i aktywność budowlaną w późniejszym okresie.

W świetle przedstawionych powyżej danych dość dobrze rysuje się osadnicza przeszłość wzgórza grodowego w Lubinie w średniowieczu i nowożytności, zmieniające się w tym czasie jego funkcje oraz uwarunkowania tych przekształceń. Położenie i samo ukształtowanie terenu nadawało wzniesieniu walory obronne, a nawet strategiczne. Nie mamy wprawdzie pewności, czy to one decydowały o powstaniu dwóch osad na sąsiadujących ze sobą wzgórzach na przełomie $\mathrm{X}$ i XI wieku, czy też większe znaczenie miała bliskość emporium wolińskiego, przeżywającego w tym czasie okres największej prosperity. Takich wątpliwości nie mamy już dla okresu pomiędzy końcem XI wieku a 2. połową następnego stulecia. Gród, pobudowany wówczas najprawdopodobniej przez krystalizującą się w tej części Pomorza władzę o charakterze wczesnopaństwowym, miał zapewnić kontrolę nad ważnym szlakiem komunikacyjnym, a jednocześnie stać się regionalnym centrum administracyjnym, religijnym, a wraz z podgrodowymi osadami najpewniej też gospodarczym. Zniszczenia, jakich doznał Lubin w czasie pomorsko-duńskich wojen były bezpośrednią przyczyną gwałtownej zmiany i utraty znaczenia politycznego i gospodarczego.

W pierwszym stuleciu po przejęciu Lubina przez kapitułę kamieńską na dawnym wzgórzu grodowym znajdował się kościół parafialny wraz z cmentarzem, będące miejscem życia religijnego mieszkańców wsi. O dalszych losach wzniesienia zadecydowały już nie tyle względy obronne, ile raczej widokowe. Być może to one miały wpływ na pobudowanie tam siedziby prepozyta kapituły; ten właśnie czynnik podkreślony został przy okazji lustracji dóbr lubińskich w XVI wieku. Ich powrót $\mathrm{w}$ ręce książąt szczecińskich w końcu stulecia oznaczał w istocie koniec wielkiej historii miejscowości. W XVIII-XX wieku wzniesienie grodowe było miejscem uprawy roli. 


\section{Bibliografia}

Źródła

$\begin{array}{ll}\text { CDP } & - \text { Codex Pomeraniae diplomaticus, t. 1, wyd. K. F. W. Has- } \\ & \text { selbach, J. G. L. Kosegarten, Greifswald 1862. } \\ \text { Herbord } & \text { Herbordi Dialogus de Vita S. Ottonis episcopi Bebenbergensis, } \\ & \text { MPH, series nova, t. VII, fasc. 3, wyd. J. Wikarjak, K. Liman, } \\ & \text { Warszawa 1974. } \\ - & \text { Pommersches Urkundenbuch, t. 1 (wyd. 2 2. Aufl.), wyd. } \\ & \text { K. Conrad, Köln-Wien 1970; t. 2, wyd. R. Prümers, Stettin } \\ \text { PUB } & 1881 ; \text { t. 6, wyd. O. Heinemann, Stettin 1906-1907. } \\ & - \\ \text { Saxo Grammaticus } & \text { Saxonis Gesta Danorum, wyd. J. Olrik, H. Raeder, Hauniae } \\ & 1931 . \\ \text { VP } & \text { S. Ottonis episcopi Babenbergensis Vita Prieflingensis, Monu- } \\ & \text { menta Poloniae Historica, series nova, t. 7, fasc. 1, wyd. J. Wi- } \\ & \text { karjak, K. Liman, Warszawa 1966. }\end{array}$

Literatura

Wykaz skrótów

BS NF - Baltische Studien, Neue Folge, Stettin

Behla R.

1888 Die vorgeschichtliche Rundwälle im östlichen Deutschland, Berlin.

Berghaus H.

1865 Landbuch des Herzogthums Stettin, von Kammin nach Hinterpommern, II Theil, Erster Band, Berlin.

Dworaczyk M., Durdyń G.

w druku Slavonic pottery, [w:] Lubin. High medieval stronghold at the mouth of the Oder, red. M. Rębkowski, H. J. Eggers.

Eggers H. J.

1960 Die wendischen Burgwälle in Mittelpommern, BS NF, t. 47, s. 13-46.

$1978 \quad$ Funde der wendisch-wikingischen Zeit in Pommern, Kiel.

Eggert O.

1927 Die Wendenzüge Waldemars I. und Knuts VI. von Dänemark nach Pommern und Mecklenburg, BS NF, t. 29, s. 1-149.

1928 Dänish-wendische Kämpfe in Pommern und Mecklenburg (1157-1200), BS NF, t. 30, z. 2 (Halbband), s. 1-76. 
Filipowiak W.

1959 Badania archeologiczno-konserwatorskie w Lubinie, pow. Wolin, Materiały Zachodniopomorskie, t. 5, s. 311-330.

1962 Wolinianie. Studium osadnicze, cz. 1: Materiaty, Szczecin.

Gaziński R.

2006 Świna jako droga wodna w średniowieczu, Przegląd Zachodniopomorski, t. 21/4, s. 139-146.

Guzikowski K.

2016 Najazdy zbrojne na Szczecin w XII wieku. Przyczyny-przebieg-skutki, [w:]

Wojna - Wojsko - Bezpieczeństwo poprzez stulecia i epoki. Studia i materiały, red. A. Aksamitowski i in., Szczecin, s. 91-100.

Hofmeister A.

1924 Zur Chronologie und Topographie der 1. Pommernfahrt des Bischofs Otto von Bamberg, Pommersche Jahrbücher, t. 22, s. 3-25.

Kiersnowscy T. i R.

1959 Wczesnośredniowieczne skarby srebrne z Pomorza. Materiały, WarszawaWrocław.

Kiersnowski R.

1951 Kamień i Wolin, Przegląd Zachodni, R. 7, nr 9-10, s. 178-225.

Kondracki J.

1998 Geografia regionalna Polski, Warszawa.

Kowalenko W.

1954 Piana, Świna i Dziwna jako szlaki osadniczo-komunikacyjne Słowiańszczyzny battyckiej VIII-XIII w., Przegląd Zachodni, 1954/1-2, s. 1-90.

Kunkel O.

1937 Burgwallforschung in Pommern, Pommersche Heimatpflege, t. 3, s. 81-92.

Küster A.

1891 Eine Sage von der Insel Wollin, Monatsblätter der Gesellschaft für pommersche Geschichte und Altertumskunde, 1891/1, s. 1-8.

Leciejewicz L.

1983 O rozwoju miast $w$ księstwie zachodniopomorskim na przełomie XII/XIII wieku, [w:] Studia z dziejów i kultury zachodniej Słowiańszczyzny, red. J Żak, J. Ostoja-Zagórski, Poznań, s. 121-153.

1993 Ośrodki władzy państwowej w księstwie zachodniopomorskim w XII w., [w:] Lokalne ośrodki władzy państwowej w XI-XII wieku w Europie Środkowo-Wschodniej, red. S. Moździoch, Wrocław, s. 63-76.

Lemcke H.

1900 Die Bau- und Kunstdenkmäler des Regierungsbezirks Stettin. Heft IV: Der Kreis Usedom-Wollin, Stettin.

Łęga W.

1930 Kultura Pomorza we wczesnem średniowieczu na podstawie wykopalisk, Toruń.

Łosiński W.

1982 Osadnictwo plemienne Pomorza (VI-X wiek), Wrocław. 
Piskorski J. M.

1990 Kolonizacja wiejska Pomorza Zachodniego $w$ XIII $i$ w poczatkach XIV wieku na tle procesów osadniczych w średniowiecznej Europie, Poznań.

Raumer von G. W.

1851 Die Insel Wollin und das Seebad Misdroy. Historische Skizze, Berlin. Rębkowski M.

2007 Chrystianizacja Pomorza Zachodniego. Studium archeologiczne, Szczecin.

2016 Ecclesia sancti Nicolai w Lubinie. Kościół grodowy z doby pomorskich misji Ottona z Bambergu, [w:] Kościoły $w$ dobie chrystianizacji, Wolińskie Spotkania Mediewistyczne, t. 3, red. M. Rębkowski, Szczecin, s. 225-238. Rębkowski M., Romanowicz P.

2015 Siedziba prepozyta kapituly kamieńskiej w Lubinie na wyspie Wolin, Kwartalnik Historii Kultury Materialnej, R. 63, nr 3, s. 391-410.

Rosik S.

2010 Conversio gentis Pomeranorum. Studium świadectwa o wydarzeniu (XII wiek), Wrocław.

Rzetelska-Feleszko E., Duma J.

1991 Dawne słowiańskie nazwy miejscowe Pomorza Szczecińskiego, Warszawa.

Spors J.

1988 Studia nad wczesnośredniowiecznymi dziejami Pomorza Zachodniego XIIpierwsza połowa XIII w., Słupsk.

1991 Organizacja kasztelańska na Pomorzu Zachodnim w XII-XIII w., Słupsk.

Stubenrauch A.

1898 Untersuchungen auf den Insel Usedom und Wollin, BS NF, t. 2, s. 65-133.

Ślaski K.

1960 Podzialy terytorialne Pomorza w XII-XIII wieku, Poznań.

Virchow R.

1872 Ausgrabungen auf der Insel Wollin, Zeitschrift für Ethnologie, t. 4, s. 58-67. Zöllner J. F.

1797 Reise durch Pommern nach Insel Rügen, Berlin.

\section{FROM DUCAL STRONGHOLD TO CHAPTER PROVOST'S RESIDENCE. LUBIN IN THE $11^{\text {TH }}-16^{T H}$ CENTURIES}

Summary

Lubin is situated on the south-western edge of Wolin island, just at the Szczecin Lagoon and mouth of the Stara Świna River to the Baltic Sea. From the locality are known seven archaeological sites dated to the Middle Ages: stronghold, cemetery and five settlements (fig. 1). The central place in this settlement complex was occupied by stronghold, situated on a high moraine hill adjacent to the Lagoon (fig. 2), which in the past created the 
possibility of control over the major water transport route, which was the Świna River connecting the Szczecin Lagoon with the Baltic Sea.

The results of excavations carried out in the years 2008-2011 in Lubin along with older discoveries and written sources created a basis for settlement reconstruction of the stronghold hill in the Middle Ages and the early post-medieval period, its functions changing over time and conditions of these transformations.

The oldest traces of settlement on the hill in the Middle Ages can be dated to the end of the $9^{\text {th }}$ century or the first half of the $10^{\text {th }}$ century. However, as late as in the second half of the $11^{\text {th }}$ century it was fortified by construction of ramparts. The stronghold, built back then most likely by early state authority forming in this part of Pomerania, was to ensure control over the important communication route, and at the same time to become a regional administration, religious, and with the adjacent settlements, probably also an economic centre. In 1124 Lubin was one of centres visited by Bishop Otto of Bamberg during his first Christianization mission in Pomerania. At that time the St Nicolas church was erected in the stronghold. Relics of this wooden temple and formed next to it cemetery were discovered in 2009-2011. Probably as early as in the first half of the $12^{\text {th }}$ century Lubin also became an important point in the structure of territorial organization of the Duchy of the West Pomerania, as centre of an administrative unit (provincia). The end of its importance was its capture and destruction in the eighth decade of the $12^{\text {th }}$ century by Danish King Valdemar I. Shortly afterwards, in 1186 or 1187, duke of Pomerania granted the cathedral chapter in Kamien the stronghold with the whole district and the church.

In the $13^{\text {th }}$ century in place of former stronghold still functioned the church, serving parish function, and the cemetery. In the next century, however, a complete change in the hill spatial organization occurred: the church was moved to the neighbouring hill, the former fortifications were levelled, and soon after a towerhouse was built, which became the seat of the provost of the cathedral chapter in Kamien during his visits to Lubin. The building was not of defensive character, and its erection in this place could have been influenced by the view of the Szczecin Lagoon. The building was demolished as late as at the end of the $16^{\text {th }}$ century, after the Lubin estate return to dukes of Szczecin. 
